Update Article

\title{
Effects of high-dilutions in behavioural models: a commentary on critical issues, from reproducibility to plausibility
}

\author{
Paolo Bellavite ${ }^{1}$, Paolo Magnani ${ }^{1}$, Anita Conforti ${ }^{2}$, \\ Marta Marzotto ${ }^{1}$, Elisabetta Zanolin²
}

\author{
[1] Department of Pathology and Diagnostics, University of Verona \\ [2] Department of Medicine and Public Health, University of Verona, Italy
}

\begin{abstract}
As part of a rigorous investigation into the effects of Gelsemium sempervirens on laboratory mice, we performed two complete series of experiments and published three scientific papers. A recent commentary has, however, called into question the reproducibility and validity of these findings. In this article we discuss the major issues raised by this critique within the framework of methodological aspects and the interpretation of results of high-dilution and homeopathic research. The charge of non-reproducibility is shown to be unfounded, because a same homeopathic medicine displayed the same direction of effects in two well-validated models (lightdark and open-field), albeit with nonlinear patterns. The double-blind protocols and statistics by means of ANOVA were performed appropriately and the difference between dilutions of Gelsemium $(5 \mathrm{cH}, 7 \mathrm{cH}, 9 \mathrm{cH}$ and $30 \mathrm{cH}$ with variations according to model) and placebo was statistically highly significant. Our investigations brought to light some problems related with the lack of activity of buspirone and diazepam (conventional anxiolytic drugs used as control) on some behavioural parameters, suggesting that Gelsemium may have broader action, and raising doubts as to the reliability of benzodiazepines as positive controls for homeopathic treatments. Concerning the plausibility of experiments in this field, disputed on the grounds of alleged lack of dose-response effect, we note that the latter is not at all uncommon, and can be accounted for by a host of possible reasons. In conclusion, our research line showed reproducible and consistent effects of Gelsemium in laboratory mice.
\end{abstract}

Keywords: Gelsemium sempervirens, reproducibility, behavioural models.

\section{Introduction}

In January 2007 we started a new line of research seeking to investigate the effects of homeopathic treatments on mice applying behavioural models used by conventional pharmacology. We described some preliminary results at a LMHI conference in 2008 [1], and later we published three papers [2-4] reporting and discussing experimental findings as they were progressively obtained.

A commentary by researchers from "Mario Negri" Institute for Pharmacological Research, in Milan [5], set forth a series of criticisms on the methodology, results and interpretation of our work seeking to demonstrate that its results are not reproducible, and suggesting that our findings are not plausible nor convincing. To frame the context, it is useful to keep in mind that recently, other members of this same Pharmacological Institute have strongly attacked the "alternative medical practices" [6] and homeopathy in particular [7]. 
In addition to some technical details that still deserve to be clarified, the topics raised in the commentary from Cervo \& Torri [5] are representative of many of the criticisms often directed to research in this field. Therefore, we believe it is in the general interest to analyse these questions, and accordingly make profit of this opportunity to tackle several key points related to the reproducibility of the scientific evidence on and the dose-response nonlinearity of high dilutions/potencies. This article begins with a brief outline of our research, followed by a discussion of various methodological and conceptual problems.

\section{Outline of methods and results}

The experimental methods we employed are described in the cited papers [2-4]. The two main tests used were open field (OF) and light-dark (LD) tests, both of which are well validated in conventional pharmacology [810]. Briefly, OF involves placing an animal in a square black-painted wood platform with surrounding walls, where the animal is free to move. The total travelled distance reflects locomotor ability, and is reduced in cases of sedation, paralysis, or impairment of movements. Time spent in the central zone is considered indicative of exploratory behaviour, and might reflect decrease in anxiety, although this OF parameter is not sensitive to all anxiolytics and may not model features of anxiety disorders. LD choice test consists of a small, secure dark compartment and a large, aversive lit compartment separated by a partition with an opening through which the animal can pass from one compartment to the other. Increase in the amount of time spent in the lit compartment is an indicator of decreased anxiety, and the number of light-dark transitions has been reported to be an indicator of exploratory activity over time. Classic anxiolytics (benzodiazepines) as well as the newer anxiolytic-like compounds (e.g. buspirone) can be tested using this paradigm. All movements of mice were video-tracked and screened by software, and all treatments and tests were performed with coded drugs/controls in double blind (operations and calculations).

In a preliminary study, we screened Aconitum napellus, Nux vomica, Gelsemium sempervirens, Atropa belladonna, Argentum nitricum, Tabacum, all in dilution/potency $5 \mathrm{cH}$ for their potential effects on animal behaviour [1]. Among the screened substances, the best "anxiolytic-like" effects were observed using Gelsemium, albeit with high variability in animal response, which precluded strong statistical evidence at that time. We repeated the protocols several times and obtained more consistent data, which were published online in September 2009 [2]. A large number of experiments performed with dilution/potency 5cH showed that Gelsemium significantly increased the time spent and the distance travelled in the central zone in OF test, while diazepam had no effect on these parameters. In a subsequent series of experiments, Gelsemium $7 \mathrm{cH}$ and $30 \mathrm{cH}$ also significantly improved the behavioural responses of mice in OF test $(\mathrm{p}<0.01$ for all tested variables). No dilution/potency of Gelsemium affected the total distance travelled, indicating that the behavioural effect was not due to unspecific changes in locomotor activity. In LD test, the mean time spent in the lit area by control and placebo-treated animals was $15.98 \%$; for mice treated with diazepam it increased to $19.91 \%(\mathrm{p}=0.047)$, while with Gelsemium $5 \mathrm{cH}$ it was $18.11 \%$ (a statistically non-significant increase). It is important to point out the nature of statistical significance: whereas in OF test the effect was significant, in LD test Gelsemium 5cH (and also 30cH) likewise showed positive effect in the same direction as diazepam, however high variability in data prevented from reaching the threshold of statistical significance. In the light of these partially positive results, we decided to continue and intensify our study of Gelsemium in high dilutions/potencies, and undertook a new experimental design with six replications of the same protocol. In order to further improve the experiment, we introduced a number of changes (in addition to the fact that mice were sourced from a different vendor, because the contract with the older one had expired): 1) because the first series of experiments had yielded the best results with OF test, this time OF test was moved to the first day to apply it on mice not habituated by any previous experiences; 2) mice were distributed two rather than four per cage to reduce the likelihood of "cage effects" (variability introduced by housing in a same cage, such as development of aggressiveness-submission, etc.); 3) a wider range of dilutions/potencies was tested (4-5-7-9$30 \mathrm{cH}$ ) on equal sample-size groups; 4) two control groups (placebo) were introduced to increase the size of the reference group, which is always fundamental for the accuracy of percentage effect calculations, and also to be able to compare the effects of two placebo treatments (which should be identical by definition) and hence 
assess the stability of the experimental system. It should also be noted that given the problem of variability in the first series of experiments (there were no references available prior to these), we used the preliminary data of OF test (namely the test which had shown the best efficacy) to compute the test power and hence to determine the sample size required for the second study. A preliminary report of the results of the second series appeared in a review published in October 2009 [3]. There, we had already noted that Gelsemium exhibited various effects on the exploratory behaviour of mice, which in some models were highly statistically significant $(p<0.001)$ in all the dilutions/potencies used, but with a complex pattern of differences depending on the experimental conditions and the test performed. The results, which included all individual experiments completed up to that time, and the lengthy discussion dealt exhaustively with these differences and their possible causes. These differences may be explained by the inherent variability of animal responses - a wellknown phenomenon in behavioural research - and by some changes made in the protocols (animal vendor, type of housing in cages, sequence of tests), which we described carefully. The last paper was published in the prestigious journal Psychopharmacology in 2010, and reported statistically significant effects of high dilutions/potencies of Gelsemium sempervirens (Gelsemium) in LD test and positive results also in OF test, albeit with lower statistical significance [4].

\section{Reproducibility}

The first point to discuss concerns "reproducibility", which is defined as "the degree of accordance between the results of the same experiment performed independently in the same or in different laboratories", and is considered a fundamental prerequisite to admit any experimental evidence [5]. According to the critique, this criterion is not met by our research because in another article published in 2009 [2], "Dilution Gelsemium 5cH gave precisely the opposite results to those reported in Psychopharmacology." Such assertion is misleading and plainly inaccurate. Contrary to our critics' claims, this second study [4] in no way contradicted the first one. It suffices to read the abstract to see that Gelsemium showed little stimulatory activity on the time spent and distance travelled in the central zone of OF with $\mathrm{p}=0.060$ in global ANOVA for groups. Anyone who knows English can appreciate that "little" is not the same as "nothing" or "opposite", while anyone who understands statistics knows that $\mathrm{p}=0.060$ means that there is $94 \%$ probability for differences between groups to be real; the cut-off point is set at 0.050 only by convention, making a potentially real result to become statistically non-significant. In any case, for further confirmation we also performed pooled data analysis of the results in both papers, and found highly significant effect of Gelsemium $5 \mathrm{cH}, 7 \mathrm{cH}$, and $30 \mathrm{cH}$ on OF parameters (time spent in the central zone) and Gelsemium $5 \mathrm{cH}, 9 \mathrm{cH}$, and $30 \mathrm{cH}$ in $\mathrm{LD}$ parameters (time spent in the light compartment and number of light-dark transitions). This analysis was presented at the XXV GIRI meeting [11] and we are currently preparing a complete report.

Reproducibility is an important issue, and since it is the first and foremost among the objections raised it needs to be fully clarified in general terms, as well as in its specific details concerning our work. If generic "reproducibility" would be defined as strictly as our critics seem to imply, no study in the world would ever be able to meet its criteria. No experiment repeated after a period of time in the same laboratory under altered experimental conditions, or in different laboratories using the same protocol can be reproduced in the same identical way. Something will always repeat, something will not, and something entirely new will appear. This is true of both laboratory and clinical studies, and it is such a commonly accepted fact that we would be surprised to learn that some researcher truly believes in absolute, perfect reproducibility. In our case, we allude to a line of research pursued over four years with an initial exploratory phase followed by confirmatory and more in-depth studies. For Gelsemium alone, a total of 14 replication experiments were performed and published, each requiring approximately one month of work.

If the authors of the critique were experts in animal behavioural tests, and would have a less prejudiced view on our publications, they would have realised the enormous difficulties we had to face due to the variability of 
mice behaviour, a well-known fact to scientists working with this type of experimental paradigms. The "ethological" tests we employed - for ethical and technical reasons that are explained in our papers - are highly sensitive to the drugs employed, but also to environmental influences. Differences between the nature and severity of external stressors, or among experimental setups might account for the high variability of results reported under different experimental conditions and by different laboratories [8; 12; 13]. The extent to which an anxiolytic compound facilitates exploratory activity has been shown to depend on its baseline level in the control group [14]. Bousta et al. [15] report some anxiolytic-like effects of Gelsemium in mice stressed by repeated electric shocks, but no such effects in normal unstressed mice. For these reasons and in connection with the well-known complexity of animal behaviour studies, we had to use a large number of animals in each group and experimental phase.

\section{Apparent discrepancies between different tests}

Furthermore, the authors of the critical letter [5] contend that our lack of commentaries on previous "contradictory findings" is a "serious omission", and that sample size by power analysis was not performed. In regards to contradictory data, this is an allegation of our critics, whereas we have already shown that this is not true, and that differences are only quantitative but not qualitative. Indeed, we could have discussed this topic more thoroughly - everything can always be improved - however, it is no less true that the putative "serious omission" is not so "serious" after all. Moreover, the review paper [3] fully reports and discusses these "apparent discrepancies", and the discussion section of another paper [4] (pgs. 541-542) tackles extensively methodological features that might account for the greater effect in LD compared to OF test, including the testing schedule.

As a fact, also we had noticed that the second series and the LD test yielded many more positive experimental results than the first one, and advanced the hypothesis [3] that mere re-subjection to behavioural tests increases the degree of baseline anxiety, and thus facilitates the tranquilising effect of the homeopathic medicine compared to the control. Although we had no proof supporting this hypothesis (since the other changes made in the protocols might have also had influence), it seemed important to mention it.

The hypothesis stating that response to drugs in behavioural tests is strongly dependent on the baseline anxiety level of animals in each particular experiment and batch of mice is also supported by recent findings in our laboratory using Ignatia amara [16]. In any case, we are comforted by the observation that "Quite possibly small changes in the experimental procedure might account for the different results"[5], with which we - and no doubt many others working in the high-dilution pharmacology field - fully agree, and that denies the putative perfect reproducibility of experimental findings. As a fact, if small changes can alter the results of such delicate experiments (a fact acknowledged by anyone who has ever worked with these models), this may explain why Gelsemium worked quantitatively better (but qualitatively comparably) in two different behavioural tests in two series of experiments.

\section{Control drugs}

Another important point is the issue of the standard control (conventional) drugs used. The letter [5] points out that diazepam, used as a conventional anxiolytic drug, was ineffective on mouse behaviour in OF test, but increased the time in the light compartment and transitions in LD test, and that this amounts to methodological weakness. "The standard anxiolytic drugs used in the two studies also gave equivocal results. In Bellavite et al., eCAM 2009, diazepam too was ineffective in one occasion but not in another, suggesting that the procedures were not altogether reliable for anxiolytics. In Magnani et al., buspirone increased the time the mice spent in the light compartment of the Light Dark test at a dose that significantly reduced mice spontaneous locomotor activity in the Open Field, giving rise to serious doubts on the specificity of the effect in the Light Dark test." This observation is not pertinent, because the reported results with buspirone are clear, even when to some extent unexpected. The absence of effect of diazepam and buspirone in OF test is reported 
and extensively discussed by us in all three papers. Buspirone showed the expected anxiolytic-like effect in one LD parameter (time spent in lit compartment), but the effect was not statistically significant in transitions between light and dark, possibly due to sedation effects of this drug [4]. Since transitions require considerable locomotion, this parameter correlates well with the reduction in mobility (distance travelled) observed in OF test (Tables 1 and 3). Certainly, it would have been better if buspirone would not have inhibited locomotion, but this could not be anticipated in the protocol, where we employed the doses ordinarily used in mice. Such effects, in any case, do not invalidate the choice between dark and light, as demonstrated by the measurements for the corresponding parameter, which support the idea that this choice truly reflects an anxiolytic-like effect of buspirone and of Gelsemium.

The fact that in our studies the reference drugs diazepam and buspirone were inactive in OF test, indicates that at least under our experimental conditions: a) OF and LD explore different emotional responses, with different sensitivity to drugs and different neurological mechanisms, b) Gelsemium, which is active in this test, has a broader action on emotional responses and behaviour. We believe and wrote that in this line of research such finding constitutes a valuable piece of new information, since it indicates that the effects of Gelsemium are also qualitatively different compared to benzodiazepines. Figure 2 on pg. 7 of the cited article [2] and figure 6 on pg. 224 of the review [3], which the authors of the critique pretend to have read carefully, are devoted to this issue. This conclusion is important for future studies of this kind, because it raises some doubts regarding the validity of using conventional anxiolytic drugs as standard controls to assess the activity of homeopathic medicines which presumably have - at least in part - different mechanisms of action.

We should point out that our results will not surprise any expert in experimental psychopharmacology, since similar variabilities in the effects of benzodiazepines dependant on the tests and doses used have been reported by many other authors [17-21]. This suggestion agrees with reports showing that anxiolytic treatments do not increase by themselves exploration in the central zone of the OF, but that they do decrease stress-induced inhibition of exploration behaviour [10]. It has been previously reported that thigmotaxis index assessed by OF test in CD1 mice did not decrease with diazepam (up to $5 \mathrm{mg} / \mathrm{kg}$ ) [20]. Other studies report anxiolytic effects of diazepam in the OF paradigm in rats [22; 23], but in mice $1 \mathrm{mg} / \mathrm{kg}$ [17; 18] or $1.5 \mathrm{mg} / \mathrm{kg}$ [19] diazepam did not show significant effects on the time spent in the OF central area. To the best of our knowledge, open field behaviours of mice were reduced by diazepam in doses that might be within the sedative-hypnotic range [17; 18]. These conflicting drives might be influenced in various ways by drugs, and small differences in the experimental conditions may have marked effects on their outcomes.

\section{Results on different strains}

In the attempt to demonstrate lack of reproducibility, the letter [5] then claims that "When the Gelsemium 5 C, $7 C$ and $30 C$ dilutions were evaluated in another strain of mice $(C 57 B L / 6 \mathrm{~J})$, again, the opposite effect from Magnani et al. was found." Actually, in the first paper [2] a short paragraph is devoted to the study of a different strain (C57BL). We report that "This yielded results qualitatively similar to those for the CD1 mice in both test models, confirming an increase in the time spent and distance traveled in the center of the OF induced by Gelsemium 5 CH." Here again, our data do not point to any lack of reproducibility, and much less to any "opposite effects". Furthermore, the above-mentioned case is part of a different study preformed two years earlier, with partially different methods, and more particularly with a different strain of mice. Therefore, since it is statistically groundless, and also owing to the differences in methods and animals, this finding cannot be legitimately used to support a charge of "opposite" results.

In the second series [4] we calculated the power of the study on the basis of available preliminary data from the first series (of course using the OF data), and described the procedure as follows: "A minimum required sample size of $n=42$ subjects per group was computed on the basis of previous experience (Bellavite et al. 2009b) and assuming a pre-established statistical power level of 0.9 and an alpha level of 0.05. Since several doses 
had to be tested in parallel, the study was conducted with six replications, each with a minimum sample size of eight." We believe that this procedure was correct and its description sufficiently clear.

There is another contentious point [5] regarding our previous review paper [3]: "To be objective, Magnani et al. cited another article by Bellavite et al., Homeopathy 2009 (page 534, left column, 10 lines from the bottom). This was a sort of review in which the authors re-proposed the data they had obtained in CD1 mice (omitting those in C57/BL6 mice!) and already published by Bellavite et al., eCAM 2009, together with the data they later submitted to Psychopharmacology. This article was cited as evidence of promising anxiolytic-like activity of Gelsemium in the Open-Field test, without mentioning the failure in the Light Dark test." The authors say "to be objective", and we sincerely hope they always are. Yet, the letter seems to show disproportionate zeal to find fault with our work and at this point it reaches a peak of misunderstanding. We are very surprised by our critics' insistence on attacking a single experiment, and by their presumption to rebuke us for not including it in a lengthy review. Surely authors have the right to include in their own reviews only the findings they judge to be truly important and interesting for readers. First, in the review published in Homeopathy [3] we did not report the data on C57/BL6 mice because they were only exploratory results obtained from a single experiment. Second, in the passage cited by the letter (page 534, left column, 10 lines from the bottom), we did not mention the failure of the LD test for the simple reason that there was no such failure. On the contrary, as noted above, we examine the reasons why the LD test might have worked better in the second series than in the first precisely in the discussion section of that same review [3] (pg 225).

The intention of the following paragraph of the critical letter [5] is likewise disputable: "Also curious is the authors' interpretation/discussion of the inconsistency of their results. An example is given by Bellavite et al., eCAM 2009. They ascribe the lack of effect of Gelsemium 5C dilution on C57/BL6 mice in the Open Field test to the smaller population and wide inter-subject data variability (SEM) (page 5, right column, lines 13 to 18). However, the number of mice tested were: 45-47 controls, 46-48 treated with 5C, 46-47 treated with 7C and 3132 treated with 30C (Table 3, on page 5). Moreover, the variability was much the same in all groups (between $6.3-9.3 \%$, Table 3, page 5)." If there is anything curious, it is this attempt to criticise one paper by assiduously looking for purported flaws in a different paper. We invite these authors to read more carefully the cited work, where there is no sign of any "curious" interpretation. First of all, we never mention any "lack of effect of Gelsemium 5C dilution on C57/BL6 mice", which is a conclusion drawn without justification. In the paper, we assert that due to the variability of responses among animals, the differences between control- and Gelsemium-treated groups (e.g. $6.11 \pm 0.80$ and $8.83 \pm 1.38 \%$ time spent in the centre, respectively) were not statistically significant $(\mathrm{p}=0.068)$ in this individual experiment. The fact that an ANOVA test on a single experiment with exploratory nature - included for completeness rather than to draw any conclusions - might not prove significant due to problems of sample size is entirely plausible, and it seems odd to us that this was not understood but used to construct such harsh criticism. Finally, everything that comes after "however" in the quoted paragraph is irrelevant, because the number of animals refers to a series of experiments with strain CD1 and not with strain C57/BL6 on which the previous reasoning is based.

\section{Lack of dose-response}

The authors [5] go on to say that: "It is also not completely correct to interpret the data from animal tests merely on the basis of statistical tests, without considering the overall picture. As a first comment, the lack of dose-response effect is important; this is a basic pharmacological/epidemiological requisite for claiming a causal relationship. The discussion on this point again seems like a "post hoc" interpretation of the results."

As a fact, we did thoroughly interpret our data with reference to the "overall picture", as it may be readily confirmed by simply reading the discussion section of the cited papers [2-4]. These examine comprehensively the issue of dose-response that in spite of having obvious and paramount importance, it is not a dogma. Most works testing different dilutions/potencies in a variety of plant, cellular and animal models report nonlinear patterns and even pseudo-sinusoidal curves, multiple peaks of activity and so forth. Since citations would take 
up too much space, here we shall simply remark that the objection adducing an alleged lack of dose-response effect arises from a misunderstanding of high-dilution pharmacology and hormesis, where nonlinear phenomena and possible physical-chemical alterations of the solvent come into play [24-27], as abundantly discussed and referenced also in the cited paper [4](page 542, paragraph 3). These are not "post-hoc" interpretations, but rather up-to-date working models, which place our results in a conceptual framework not compatible with a simple dose-response relation [28-31]. Data that do not fall within linear dose-response relationships are not at all uncommon in behavioural pharmacology, and they occur due to a host of possible reasons. Hence also this side of criticism is unwarranted, and betrays poor acquaintance with the wide and growing literature on high-dilution pharmacology.

\section{Methodological issues concerning reproducibility}

Again with reference to reproducibility, the letter [5] objects: "In addition, different weights are given to inconsistent evidence. Although both tests were considered primary, Bellavite et al., eCAM 2009, interpreted the increase in time and distance travelled in the center of the Open Field as evidence of Gelsemium' anxiolytic-like activity. The fact that Gelsemium was completely inactive in the Light Dark test, and the evidence of diazepaminduced opposite effects was considered merely secondary." This critique, which artificially weaves together a series of issues cherry-picked from different papers with a series of the authors' opinions, runs directly against evidence. Besides the fact that our evidence is not in the least "inconsistent", we never discussed data in terms of primary or secondary effects, since both tests have equal importance. Neither did we notice "opposite" effects of diazepam in the tests that measure "anxiolytic-like" pharmacological activity. To be sure, the concept of "anxiolytic-like", widely used in experimental pharmacology, is extremely generic, and we have always been careful to emphasise this in our papers, especially in the discussion section. It is fully legitimate to take different measures from a single test and to use them to make different interpretative points. Thus, in the OF, measures related to activity in the central zone (entrance into, time spent and distance travelled) can be used as indices of anxiety-related behaviour. In contrast, total distance travelled (or even peripheral distance travelled) may be used as indices of locomotor activity. We refer in particular to the discussion in the paper published in Psychopharmacology [4](p. 541-542), where we explain that these two tests explore distinct behavioural aspects that are affected by medicines in different ways, as also borne out by their differing sensitivity to conventional drug buspirone. We also discuss the pertinence of OF and LD tests to the two types of anxiety, namely "trait" and "state" anxiety.

The authors of the critique [5] then put a simple question: "Another methodological problem is the lack of a clear description of the criterion used to consider the transition between compartments in the Light Dark test: only the head, the head plus forepaws or all four paws?" Frankly, this objection seems to us frivolous and contrived. It is the kind of question that might have more appropriately been raised by the journal referees as a point of interest, rather than in an elaborate critique of our work. In any case, the answer is that a transition was counted (in double blind) in the analysis of the video recordings when the animal passed the boundary with all four paws. In fact, if our critics would have taken the time to read the citations for the method we used [9], they would have discovered precisely that "Entry into a chamber is defined as the placement of all four paws in the chamber."

The critique [5] also raises a point regarding statistics: "Finally, for ANOVA statistical analysis since the effect in control groups seems to differ, it would be more appropriate, though more conservative, to compare the five treatment groups with only one control group and then to repeat comparison using the other control. In this way it would have been possible to assess the stability of the results. Instead, analysis was based on the mean of the results of two control groups and the two control groups separately as well." ANOVA was certainly performed appropriately, since we compared each treatment group composed of 48 mice against 96 untreated mice in order to have a larger control group, and this is correct. In ANOVA, the usual procedure is for each treatment group to be compared to a single control group, which is what we did. Comparing each treatment to each of both controls would have introduced more problems of multiple comparison for no useful purpose, and 
resulting in loss of power. Moreover, the two control groups showed similar variability and could therefore be pooled without qualms. The inclusion of two subgroups that do not have activity by definition did not inflate the effects of treatment; we have analysed data and experimentally confirmed this point. There were no significant differences between the two control groups, and under these conditions it is not uncommon to pool datasets. Of course, this would reduce the variance within the control condition, thus making detection of a treatment effect somewhat easier - if existing. However, as this statistical technique is neither improper nor peculiar to our paper, the criticism cannot be seen as fair.

\section{Plausibility}

At the end, Cervo \& Torri write [5]: "In conclusion, when an experiment has low biological plausibility - as in the case of highly diluted products - it is important to be extremely critical in conducting and interpreting the results."

We believe that critical thinking is always essential: not only when plausibility is low, but also when it is high as it may seem in some fields of conventional pharmacology. Otherwise, paradigms prevailing in medical thinking and even wrong theories endowed with apparently high plausibility are likely to continue dominating without critical control.

As a fact, we did adopt a fully critical approach in our experiments, and an unbiased perusal of them should be enough to confirm the overall validity of our findings and interpretations. Moreover, effects of Gelsemium in neurological models have been independently reported by other authors using low [32; 33] or high [15; 34] dilutions/potencies, while working hypotheses on its mechanism of action have already been put forward [3; 34].

We have been working in this field for over 20 years [35], and are thus perfectly aware of the issues related to the "plausibility" of high-dilution pharmacology, particularly when using dilutions beyond Avogadro's constant. Needless to say, there is a growing body of literature on the possible physical-chemical basis of retention of pharmacological activity in highly diluted solutions, but this is often ignored in criticisms by individuals not acquainted with this field. The issue on the biological plausibility of homeopathy has been discussed elsewhere by us [27; 36-38] as well as by several other authors [39-41].

Plausibility - often used as an argument to diminish the credibility of homeopathy - as a suitable yardstick to evaluate innovative research is a moot point. In any case, doubts as to plausibility should vanish in the face of experimental evidence, just as the Ptolemaic geocentric model, which reigned for centuries as the "most plausible", was swept away by the Copernican demonstrations. Of course, nonlinearity may seem implausible to those who think in a linear fashion. Increased activity on dilution or dose-response experiments where peaks of activity alternate with non-activity may seem incomprehensible and even absurd to those who ignore modern self-organization theories, including systems biology, networks, and chaos. According to very serious hypotheses, the homeopathic serial dilutions and succussions might induce a process of increasing physical structuring or dissipative structures with self-organization of fractal geometric shapes generated by iteration processes and saving self-similarity at different scales [30; 42-47].

In conclusion, our research reported for the first time, with rigorous methods and consistent results, the effect of Gelsemium in high dilutions/potencies on two strongly validated behavioural paradigms in laboratory mice. These effects point to "anxiolytic-like" activity in general terms, which differs from that of conventional drugs and is very sensitive to the individual responsiveness of animals and to the experimental conditions.

\section{References}


[1] Magnani P, Conforti A, Bellavite P. Effects of homeopathic drugs on the anxiety-like behaviour in mice. Proceedings of 63rd world congress of the Liga Medicorum Homeopathica Internationalis. 2008. Ostend, LMHI edition (CD-ROM).

[2] Bellavite P, Magnani P, Zanolin E, Conforti A. Homeopathic doses of Gelsemium sempervirens improve the behavior of mice in response to novel environments. Evid Based Complement Alternat Med 2011; 2011:1-10 (e-pub 14 sept 2009).

[3] Bellavite P, Magnani P, Marzotto M, Conforti A. Assays of homeopathic remedies in rodent behavioural and psychopathological models. Homeopathy 2009; 98:208-227.

[4] Magnani P, Conforti A, Zanolin E, Marzotto M, Bellavite P. Dose-effect study of Gelsemium sempervirens in high dilutions on anxiety-related responses in mice. Psychopharmacology (Berl) 2010; 210:533-545.

[5] Cervo L, Torri V. Comment on: "Dose-effect study of Gelsemium sempervirens in high dilutions on anxietyrelated responses in mice" (Magnani P, Conforti A, Zanolin E, Marzotto $\mathrm{M}$ and Bellavite P, Psychopharmacology, 2010). Psychopharmacology (Berl) e-pub 19-11-2011.

[6] Garattini S, Bertelé V. Alternative medical practices: flashbacks from the Dark Ages. Eur J Intern Med 2010; $21: 245-246$.

[7] Garattini S, Bertelé V. Homoeopathy: not a matter for drug-regulatory authorities. Lancet 2009; 374:15781580.

[8] Prut L, Belzung C. The open field as a paradigm to measure the effects of drugs on anxiety-like behaviors: a review. Eur J Pharmacol 2003; 463:3-33.

[9] Bourin M, Hascoet M. The mouse light/dark box test. Eur J Pharmacol 2003; 463:55-65.

[10] Bourin M, Petit-Demouliere B, Dhonnchadha BN, Hascoet M. Animal models of anxiety in mice. Fundam Clin Pharmacol 2007; 21:567-574.

[11] Bellavite P, Magnani P, Marzotto M, Cristofoletti M, Zanolin M, Conforti A. Mice behavioural models with pooled data analysis of Gelsemium studies and new findings about Ignatia and Aconitum. Int J High Dilution Res [online]. 2011 [cited 2011 Nov 30]; 10(36): 198-200. Proceedings of the XXV GIRI Symposium and VIII CBFH; 2011 Sep 04-07; Foz do Iguaçu (Brazil). GIRI and ABFH; 2011; Available from:

http://www.feg.unesp.br/ ojs/index.php/ijhdr/article/view/523/536

[12] Mineur YS, Belzung C, Crusio WE. Effects of unpredictable chronic mild stress on anxiety and depression-like behavior in mice. Behav Brain Res 2006; 175:43-50.

[13] Belzung C, Griebel G. Measuring normal and pathological anxiety-like behaviour in mice: a review. Behav Brain Res 2001; 125:141-149.

[14] Hascoet M, Bourin M, Dhonnchadha BA. The mouse light-dark paradigm: a review. Prog Neuropsychopharmacol Biol Psychiatry 2001; 25:141-166.

[15] Bousta D, Soulimani R, Jarmouni I, Belon P, Falla J, Foment N, Younos C. Neurotropic, immunological and gastric effects of low doses of Atropa belladonna L., Gelsemium sempervirens L. and Poumon histamine in stressed mice. J Ethnopharmacol 2001; 74:205-215.

[16] Marzotto M, Conforti A, Magnani P, Zanolin ME, Bellavite P. Effects of Ignatia amara in mouse behavioural models. Homeopathy 2012; 101 (in press). 
[17] Simon P, Dupuis R, Costentin J. Thigmotaxis as an index of anxiety in mice. Influence of dopaminergic transmissions. Behav Brain Res 1994; 61:59-64.

[18] Crawley JN. Exploratory behavior models of anxiety in mice. Neurosci Biobehav Rev 1985; 9:37-44.

[19] Choleris E, Thomas AW, Kavaliers M, Prato FS. A detailed ethological analysis of the mouse open field test: effects of diazepam, chlordiazepoxide and an extremely low frequency pulsed magnetic field. Neurosci Biobehav Rev 2001; 25:235-260.

[20] Ennaceur A, Michalikova S, van RR, Chazot PL. Are benzodiazepines really anxiolytic? Evidence from a 3D maze spatial navigation task. Behav Brain Res 2008; 188:136-153.

[21] Ennaceur A, Michalikova S, van RR, Chazot PL. Tolerance, sensitization and dependence to diazepam in Balb/c mice exposed to a novel open space anxiety test. Behav Brain Res 2010; 209:154-164.

[22] Nazar M, Jessa M, Plaznik A. Benzodiazepine-GABAA receptor complex ligands in two models of anxiety. J Neural Transm 1997; 104:733-746.

[23] Kong WX, Chen SW, Li YL, Zhang YJ, Wang R, Min L, Mi X. Effects of taurine on rat behaviors in three anxiety models. Pharmacol Biochem Behav 2006; 83:271-276.

[24] Calabrese EJ. Hormesis: why it is important to toxicology and toxicologists. Environ Toxicol Chem 2008; 27:1451-1474.

[25] Jonas WB, Ives JA. Should we explore the clinical utility of hormesis? Hum Exp Toxicol 2008; 27:123-127.

[26] Calabrese EJ, Jonas WB. Homeopathy: clarifying its relationship to hormesis. Hum Exp Toxicol 2010; 29:531-536.

[27] Bellavite P, Chirumbolo S, Marzotto M. Hormesis and its relationship with homeopathy. Hum Exp Toxicol 2010; 16:11-18.

[28] Torres JL, Ruiz G. Stochastic resonance and the homoeopathic effect. Br Homeopath J 1996; 85:134-140.

[29] Marotta D, Marini A, Banaudha K, Maharaj SV, Jonas WB. Nonlinear effects of glutamate and KCl on glutamate toxicity in cultured rat cerebellar neurons. Int J Neurosci 2003; 113:491-502.

[30] Bellavite P: Complexity science and homeopathy. A synthetic overview. Homeopathy 2003; 92:203-212.

[31] Ruiz-Vega G, Estevez-Delgado G. Non-linearity modeling of ultra-dilutions: the histamine disturbances case; in Bonamin LV (ed): Signals and Images. Contributions and contradictions about high dilution research. Springer Science, 2008, pp 67-82.

[32] Dutt V, Dhar VJ, Sharma A. Antianxiety activity of Gelsemium sempervirens. Pharm Biol 2010; 48:10911096.

[33] Venard C, Boujedaini N, Belon P, Mensah-Nyagan AG, Patte-Mensah C. Regulation of neurosteroid allopregnanolone biosynthesis in the rat spinal cord by glycine and the alkaloidal analogs strychnine and gelsemine. Neuroscience 22-4-2008; 153:154-161.

[34] Venard C, Boujedaini N, Mensah-Nyagan AG, Patte-Mensah C. Comparative analysis of gelsemine and Gelsemium sempervirens activity on neurosteroid allopregnanolone formation in the spinal cord and limbic system. Evid Based Complement Alternat Med 2011; doi: 10.1093/ecam/nep083:1-10. 
[35] Bellavite P: Research in homeopathy: data, problems and prospect. Ann Ist Super Sanità 1990; 26:179187.

[36] Bellavite P, Andrioli G, Lussignoli S, Signorini A, Ortolani R, Conforti A. Scientific reappraisal of the "Principle of Similarity". Med Hypoth 1997; 49:203-212.

[37] Bellavite P, Ortolani R, Pontarollo F, Pitari G, Conforti A. Immunology and Homeopathy. 5. The Rationale of the 'Simile'. Evid Based Complement Alternat Med 2007; 4:149-163.

[38] Bellavite P: On the plausibility of the homeopathic similitude. Bioethics 2011; 26 (in press).

[39] Schwartz GE, Russek LG, Bell IR, Riley D. Plausibility of homeopathy and conventional chemical therapy: the systemic memory resonance hypothesis. Med Hypoth 2000; 54:634-637.

[40] Rao ML, Roy R, Bell IR, Hoover R. The defining role of structure (including epitaxy) in the plausibility of homeopathy. Homeopathy 2007; 96:175-182.

[41] Fisher P. Bayes, bias and plausibility. Homeopathy 2008; 97:167-168.

[42] Shepperd J. Chaos theory: Implications for homeopathy. J Am Inst Homeopathy 1994; 87:22-29.

[43] Bellavite P, Signorini A. The emerging science of homeopathy: complexity, biodynamics, and nanopharmacology. Berkeley (CA), North Atlantic, 2002.

[44] Bell IR, Baldwin CM, Schwartz GE. Translating a nonlinear systems theory model for homeopathy into empirical tests. Altern Ther Health Med 2002; 8:58-66.

[45] Teut M. Homeopathy between vital force and self-organization. Forsch Komplementarmed Klass Naturheilkd 2001;8:162-167.

[46] Elia V, Napoli E, Germano R. The 'Memory of Water': an almost deciphered enigma. Dissipative structures in extremely dilute aqueous solutions. Homeopathy 2007; 96:163-169.

[47] Milgrom LR: Falling trees, fractals, and sophistry: some philosophical "biohazards" en route to reconciling biomedicine and homeopathy. J Altern Complement Med 2009; 15:1247-1254.

\section{Efeitos de Altas Diluições em modelos comportamentais: comentários sobre temas críticos, da reprodutibilidade a plausibilidade}

\section{RESUMO}

Como parte da investigação rigorosa sobre os efeitos do Gelsemium sempervirens em camundongos de laboratório, realizamos dois conjuntos completos de experimentos o que deu origem a três artigos sobre o tema. Porém, uma crítica recentemente publicada questionou a reprodutibilidade e validade desses resultados. Neste artigo, discutimos os pontos principais levantados pelos críticos, com base em aspectos metodológicos e a interpretação de resultados de pesquisas em altas diluições e homeopatia. Mostramos que a crítica sobre a não reprodutibilidade é infundada porque um mesmo medicamento sempre gerou efeitos na mesma direção, em dois modelos bem validados (claro-escuro e campo aberto), embora com padrões nãolineares. Os protocolos duplo-cegos e a estatística ANOVA foram devidamente realizados e as diferenças 
estatísticas entre as diluições de Gelsemiun semprevirens $(5 \mathrm{cH}, 7 \mathrm{cH}, 9 \mathrm{cH}$ e $30 \mathrm{cH}$, com variações de acordo com o modelo) e o placebo foram altamente significativa. Nossas pesquisas trouxeram a tona alguns problemas relacionados com a atividade da buspirona e diazepam (drogas anxiolíticas convencionais usadas como controle) em alguns parâmetros comportamentais, sugerindo que Gelsemiun pode ter uma ação mais ampla, levantando dúvidas sobre o uso de benzodiazepinas como controle positivo para tratamentos homeopáticos. Em relação a plausividade dos experimentos nessa area e a alegada falta de efeito dose-resposta, notamos que estas não são de todo incomuns, e podem ser explicadas por uma série de possíveis razões. Em conclusão, nossa linha de pesquisa mostrou reprodutibilidade e efeitos consistentes, para os efeitos do Gelsemiun em camundongos de laboratório.

Keywords: Gelsemium sempervirens, reprodutibilidade, modelos comportamentais.

\section{Efectos de las Altas Diluciones em modelos comportamentales: comentários respecto a temas críticos, da reprodutibilidad a la plausibilidad}

\section{RESUMEN}

Como parte de una rigurosa investigación de los efectos de Gelsemium sempervirens en ratones de laboratorio, realizamos dos series completas de experimentos y publicamos tres artículos científicos. Sin embargo, un comentario reciente critica la reproductibilidad y validad de nuestros resultados. En este artículo discutimos los aspectos principales de esta crítica en relación a los aspectos metodológicos e interpretativos de la investigación en homeopatía y altas diluciones. La acusación de falta de reproductibilidad carece de fundamentos, pues los efectos de un mismo medicamento homeopático mostraron una misma dirección en dos modelos bien validados (luz/oscuridad y campo abierto), empero, con respuestas no lineares. Los protocolos doble ciego y cálculos estadísticos mediante ANOVA fueron ejecutados correctamente y la diferencia entre diluciones de Gelsemium $(5 \mathrm{cH}, 7 \mathrm{cH}, 9 \mathrm{cH}$ y $30 \mathrm{cH}$ según el modelo) y placebo fueron notablemente significativas. Nuestra rigurosa investigación evidenció problemas relacionados con la inactividad de buspirona y diazepam (drogas ansiolíticas convencionales utilizadas como control) en algunos parámetros conductuales, lo que indica que Gelsemium puede tener una acción más amplia y que la confiabilidad de las benzodiazepinas como controles positivos de tratamientos homeopáticos debe ser cuestionada. Con respecto a la plausibilidad de los experimentos en este campo, cuestionados con base en la supuesta ausencia de efecto dosis-respuesta, recordamos que no se trata de nada poco común y que puede ser explicada por innúmeros factores. Concluyendo, nuestra línea de investigación demostró que Gelsemium causa efectos reproducibles y consistentes en ratones de laboratorio.

Palabras clave: Gelsemium sempervirens, reproductibilidad, modelos comportamentales.

\section{(c) BY-NC-ND Licensed to GIRI}

Support: The research was supported by a grant of Boiron Laboratories to University of Verona. The authors had full access to all the data in this study and take complete responsibility for the integrity of the data and the accuracy of the data analysis.

Conflict of interest: authors declare there is no conflict of interest.

Received: 10 November 2011; Revised: 12 December 2011; Published: 20 December 2011.

Correspondence author: Paolo Bellavite, paolo.bellavite@univr.it, www.paolobellavite.it

How to cite this article: Bellavite P, Magnani P, Conforti A, Marzotto M, Zanolin E. Effects of high-dilutions in behavioural models: a commentary on critical issues, from reproducibility to plausibility. Int J High Dilution Res [online]. 2011 [cited YYY Month dd]; 10(37): $325-337 . \quad$ Available from:

http://www.feg.unesp.br/ ojs/index.php/ijhdr/article/view/532/550 